\title{
First record of a less known Asian moonflower (Ipomoea aspera: Convolvulaceae) from India
}

\author{
Barbhuiya H.A. ${ }^{1 *}$, Salunkhe C.K. ${ }^{1}$, Verma D. ${ }^{2}$ \& S. Dey ${ }^{3}$ \\ ${ }^{1}$ Landscape and Cosmetic Maintenance Section, Architectural and Structural Engineering Division, \\ Bhabha Atomic Research Centre, Trombay, Mumbai, Maharashtra- 400 085, India. \\ ${ }^{2}$ Botanical Survey of India, Northern Regional Centre, Dehradun, Uttarakhand- 248 195, India. \\ ${ }^{3}$ Department of Botany, Nagaland University, Lumami, Nagaland- 798 627, India. \\ *E-mail: hahmed@barc.gov.in
}

\begin{abstract}
Ipomoea aspera (Choisy) Vatke, an Asian moonflower is reported here for the first time from India. A brief description of the plant along with photographs and distribution map are provided to facilitate its future unambiguous identification. Its taxonomic relationships with other closely allied taxa are examined and discussed.
\end{abstract}

Keywords: Ipomoea, Sect. Calonyction, Moon Flower, New record, Pollination syndrome.

\section{Introduction}

Ipomoea L. is a large and diverse genus in the morning glory family Convolvulaceae and comprises over 600 species of vines and shrubs. The genus is distributed throughout the tropics and subtropics (Fang \& Staples, 1995; Miller et al., 2004; Staples, 2010; Khalik, 2013) and majority are found in the Americas (Austin \& Huaman, 1996). In India, the genus is represented by approximately 57 species (Clarke, 1883; Johri, 1984). Chowdhury (2005) listed 18 species from the state of Assam.

Moonflowers are night-flowering species with a distinctive suite of floral characters: white salverform corolla, sweet fragrance, often exserted stamens and stigma. These conform to a nocturnal moth pollination syndrome (Staples \& Traiperm, 2008). Gunn (1972) recognized four species of moonflower morning glories in temperate America, which he assembled in Ipomoea sect. Calonyction (Choisy) Griseb. This assemblage was circumscribed on the basis of warty or fleshy spinous stems, simple leaves, axillary dichasia, and salverform corolla with a prominent tube

Received: 01.07.2018; Revised \& Accepted: 06.06.2019 Published Online: 30.09.2019 (hawkmoth pollination syndrome). However, McDonald (1993) had the opinion that, nocturnal moth pollination syndrome has multiple origins in Ipomoea and evolved independently yet in other sections of the genus.

The Asian night-flowering species of Ipomoea (moonflowers) have not been taxonomically studied in the same degree of thoroughness as their tropical American counterparts (Staples \& Traiperm, 2008). The Asian night flowering group comprises less than 10 taxa and the species Ipomoea aspera (Choisy) Vatke is one of them. It was first described by Choisy (1834) as Calonyction asperum Choisy based on collection made by F. de Silva from Sylhet district of Bangladesh. Clarke (1883) reduced C. asperum under the synonymy of $I$. grandiflora sensu C.B.Clarke ( $=I$. violacea L.). Thereafter, the species was lingered in obscurity, as there is no mention of the species in regional floras (Clarke, 1939; Deb, 1983; Khan, 1985; Haridasan \& Rao, 1987; Mill, 1999; Giri et al., 2008; Sinha, 2012; Mao et al., 2016, 2017). Recently, Staples and Traiperm (2008) recognized I. aspera as a distinct species and reported its occurrence from Myanmar and Thailand.

During a field study in 2011 at Borail Wildlife Sanctuary located in Cachar district of Assam, the first author collected a few specimens of the plant in flowering condition. After critical morphological study, the specimens are identified as I. aspera, which forms a new addition to the flora of India.

Ipomoea aspera (Choisy) Vatke, Linnaea 43: 508. 1882; Staples \& Traiperm, Thai For. Bull. (Bot.) 36: 95. 2008; Staples in Santisuk et al., Fl. Thailand 10(3): 409. 2010. Calonyction asperum Choisy, Mém. Soc. Phys. Genève 6: 442.1834. Convolvulus asper Wall., Numer. List no. 1388. 1829. nom. inval. 
Type: BANGLADESH, Sillet (Sylhet), s.d., Wallich Cat. No. 1388 (syntype G-DC-00135407 digital image!).

Fig. 1

Herbaceous climber. Stems terete with short fleshy spines, greenish, 2.5-4.6 $\mathrm{mm}$ in diam. Leaves ovate-cordate, $8.5-13.5 \times 7.5-11.3 \mathrm{~cm}$, cordate at base, caudate-acuminate at apex, margins sparsely dentate (never deeply lobed), rarely entire, glabrous, lateral nerves 7-8 pairs; petioles slender, $5.5-9.5 \mathrm{~cm}$ long. Flowers nocturnal, solitary, axillary; pedicels stout, $1.1-1.6 \mathrm{~cm}$ long, gradually thickened upwards. Sepals unequal; outer 2 smaller, ovate-elliptic, $13.5-14.5 \times 8.5-9.5 \mathrm{~mm}$, obtuse at apex; inner ones larger, oblong-elliptic, 17.2-21.5 $\times$ 8.4-12.6 mm, margins thinner, apex rounded, mucronate. Corolla salverform, white, greenish outside; tube 8.5-9.7 cm long; limb shallowly 5-lobed, 6-7 cm in diam., midpetaline bands distinct, white or creamy. Stamens inserted near the base of corolla tube; anthers elliptic-oblong, longitudinally dehiscent. Carpels included, ovary glabrous. Fruits not seen.

Flowering: October -November.

Habitat: On shady hill slopes in evergreen forest at altitudes ranging from $58-120 \mathrm{~m}$. It was found climbing on shrubs and trees present in the vicinity, occasionally forming dense clumps. The main components of the forest were viz. Schima wallichii (DC.) Korth. (Theaceae), Callicarpa arborea Roxb. (Lamiaceae), Ficus cyrtophylla (Wall. ex Miq.) Miq. (Moraceae), Dendrocnide sinuata (Blume) Chew, Oreocnide integrifolia (Gaudich.) Miq. (Urticaceae),
Ardisia khasiana C.B. Clarke (Primulaceae), Macropanax dispermus (Blume) Kuntze (Araliaceae), Psychotria monticola Kurz (Rubiaceae), etc.

Distribution: India (Assam), Bangladesh (Sylhet), Myanmar (Yangon, Thaninthanyi), Thailand (Loei, Kanchanaburi, Saraburi).

Fig. 2

Specimen examined: INDIA, Assam, Cachar, Borail Wildlife Sanctuary, Kalain Range, 15 no. Hill, $25^{\circ} 01^{\prime} 05.08^{\prime \prime} \mathrm{N}, \quad 92^{\circ} 37^{\prime} 43.74^{\prime \prime} \mathrm{E}$, alt. c. $120 \mathrm{~m}, 11.11 .2011$, H.A. Barbhuiya 800 (HBARC-00006401!).

Notes: Ipomoea aspera shows affinity with I. aculeata Blume and I. violacea L. in having salverform corolla with a long narrow tube, white midpetaline bands, obtuse sepals and hairy nature of seeds. However, the former differs from the latter in having shorter outer sepals and insertion of stamens near the base of corolla tube against the outer sepals slightly longer than the inner ones and stamens usually inserted near the middle of the corolla tube in I. aculeata. I. aspera also differs from I. violacea by the presence of dentate leaf margins, soft muricate or spiny stem, seed edges with long $(c .10 \mathrm{~mm})$ yellowish, wavy hairs. Whereas in I. violacea leaves are always entire, the stem is a little bit woody at base, surface verrucose or warty, often longitudinally wrinkled and seeds with short $(c .3 \mathrm{~mm})$ black-velvety, hairs on the edges (Staples, 2010). I. aspera also shows a close affinity with Malesian I. trichosperma Blume. However, the latter is distinct from the former in having woody stems with smooth or minutely verrucose surface, deeply lobed leaves and corolla
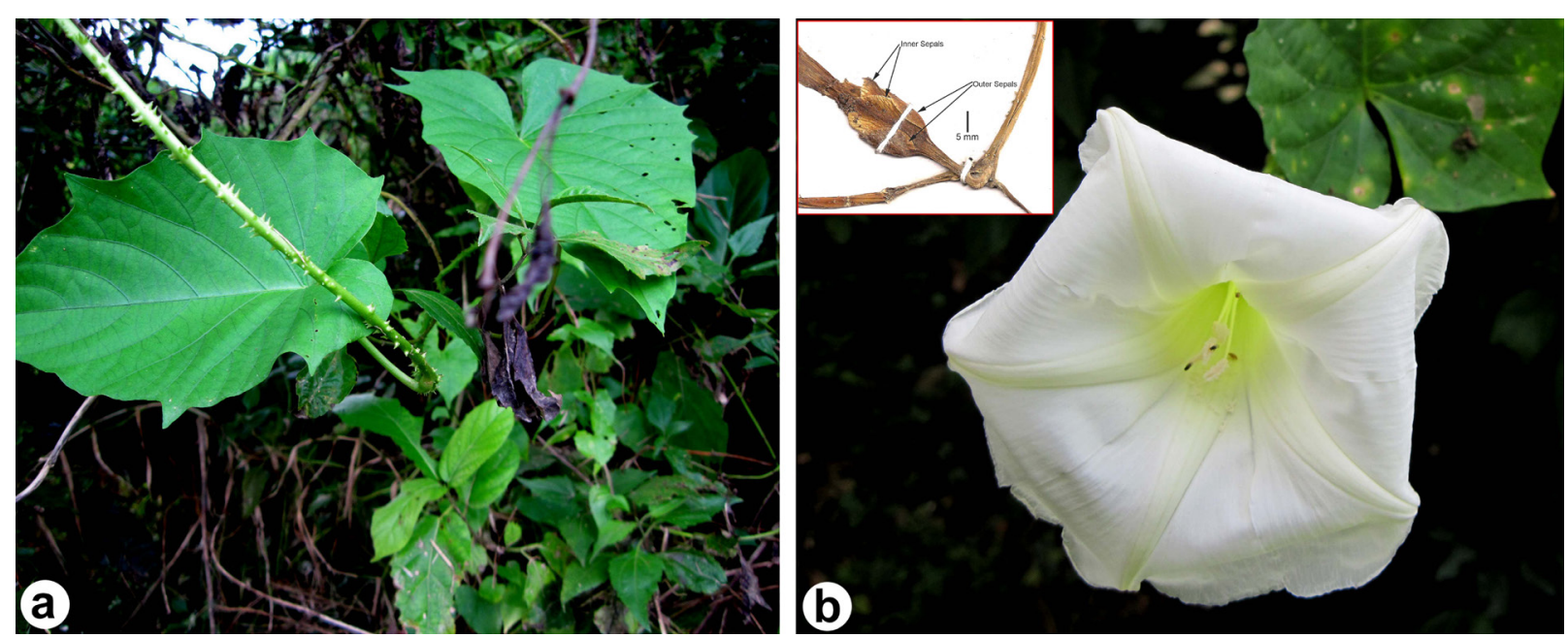

Fig. 1. Ipomoea aspera (Choisy) Vatke. a. Leaves with a portion of muricate stem; b. Front view of the flower showing 5-lobed corolla limb, midpetaline bands and stamens. Flower base showing outer and inner sepals (in caption). 


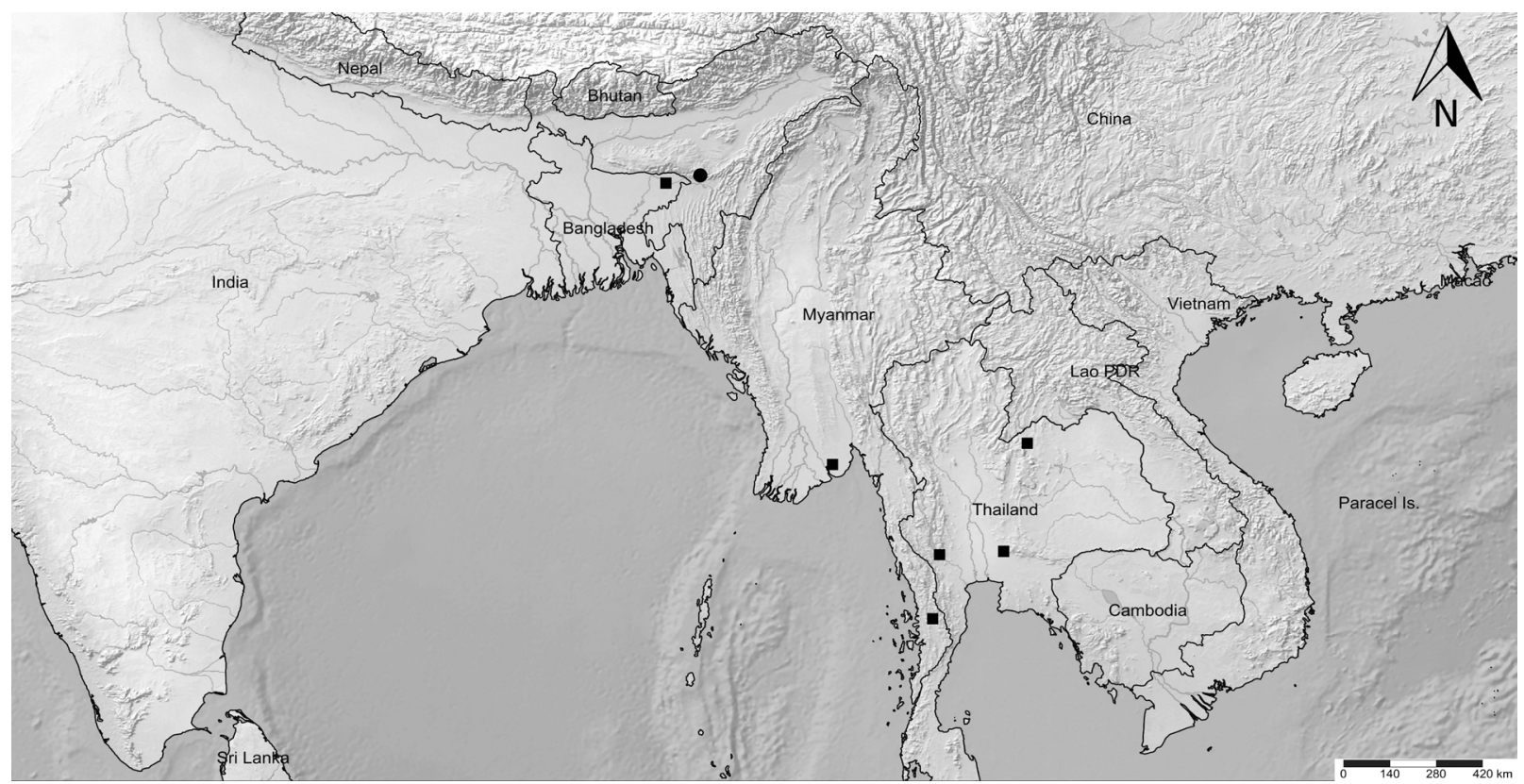

Fig. 2. Distribution map of Ipomoea aspera (Choisy) Vatke. Square

indicates the previously known localities while circle

(n) indicates the currently reported locality. Map Created with Simple Mappr, http://www.simplemappr.net (Shorthouse, 2010).

with reddish midpetaline bands (Van Ooststroom, 1940; Van Ooststroom \& Hoogland, 1953).

\section{Acknowledgements}

We are thankful to the Assam Forest Department for permission to conduct botanical explorations in protected areas, Dr. G.W. Staples, (Herbarium, Royal Botanic Gardens, Kew, U.K.) for valuable comments on the identity of the specimens and to Dr. R.K. Choudhary, (Biodiversity \& Palaeobiology Group, Agharkar Research Institute, Pune) for valuable help.

\section{Literature Cited}

AUSTIN D.F. \& Z. HUAMAN 1996. A synopsis of Ipomoea (Convolvulaceae) in the Americas. Taxon 45: 3-38.

CHOISY J.D. 1834. Convolvulaceae orientales. Mémoires de la Société de Physiqueetd' histoire naturelle de Genéve $6(2): 383-502$.

CHOWDHURY S. 2005. Assam's Flora (Present status of vascular plants). Assam Science Technology and Environment Council, Guwahati.

CLARKE C.B. 1883. Convolvulaceae. In: HOOKER J.D. (Ed.), Flora of British India. Volume 4. L. Reeve \& Co. London. pp. 179-228.

CLARKE C.B. 1939. Convolvulaceae. In: KANJILAL U.N., DAS P., KANJILAL P.C. \& R.N. DE (Eds.), Flora of Assam. Volume 3. (Caprifoliaceae to Plantaginaceae).
Government of Assam, Shillong. pp. 338-362.

DEB D.B. 1983. The Flora of Tripura State. Volume 2. Today and Tomorrow's Printers and Publishers, New Delhi.

FANG R. \& G. STAPLES 1995. Convolvulaceae In: WU Z.Y. \& P.H. RAVEN (Eds.), Flora of China. Volume 16. (Gentianaceae through Boraginaceae). Science Press, Beijing, and Missouri Botanical Garden Press, St. Louis. pp. 271-325.

GIRI G.S., PARMANIK A. \& H.J. CHOWDHERY 2008. Materials for the Flora of Arunachal Pradesh. Volume 2. (Asteraceae-Ceratophyllaceae). Botanical Survey of India, Kolkata.

GUNN C.R. 1972. Moonflowers, Ipomoea section Calonyction, in temperate North America. Brittonia 24: 150-168.

HARIDASAN K. \& R.R. RAO 1987. Forest Flora of Meghalaya. Volume 2. (Caprifoliaceae to Salicaceae). Bishen Singh Mahendra Pal Singh, Dehra Dun.

JOHRI S.C. 1984. The genus Ipomoea L. in Rajasthan. Journal of Economic Taxonomic Botany 5(5): 1113-1142.

KHALIK K.A. 2013. Systematic implications of seed coat diversity in some representatives of the genus Ipomoea (Convolvulaceae). Turkish Journal of Botany 37: 811-824.

KHAN M.S. 1985. Convolvulaceae. In: KHAN M.S. (ed.), Flora of Bangladesh. No. 30. Bangladesh Agricultural Research Council, Dhaka. pp. 1-59. 
MAO A.A., SINHA B.K., VERMA D. \& N. SARMA 2016. Checklist of Flora of Meghalaya. Meghalaya Biodiversity Board, Shillong.

MAO A.A., ODYUO N., VERMA D. \& P. SINGH 2017. Checklist of Flora of Nagaland. Botanical Survey of India, Kolkata.

MCDONALD J.A. 1993. A new species of Ipomoea (Convolvulaceae) from Costa Rica and notes on the circumscription of section Calonyction (Choisy) Griseb. Harvard Papers in Botany 1(4): 53-56.

MILLER R.E., MCDONALD J.A. \& P.S. MANOS 2004. Systematics of Ipomoea subgenus Quamoclit (Convolvulaceae) based on its sequence data and a Bayesian phylogenetic analysis. American Journal of Botany 91(8): 1208-1218.

MILL R.R. 1999. Convolvulaceae. In: GRIERSON A.J.C. \& D.G. LONG (Eds.), Flora of Bhutan. Volume 2, Part 2. Royal Botanic Garden Edinburgh, U.K. \& The Royal Government of Bhutan. pp. 834-862.

SINHA G.P. 2012. Convolvulaceae. In: SINHA G.P., SINGH D.K., \& K.P. SINGH, (eds.), Flora of Mizoram Volume 2. (Campanulaceae to Salicaceae). Botanical Survey of India, Kolkata. pp. 137-154.
SHORTHOUSE D.P. 2010. SimpleMappr, an online tool to produce publication-quality point maps. Available from http://www.simplemappr.net. (Accessed 30.07.2018).

STAPLES G. 2010. Convolvulaceae. In: SANTISUK T., LARSEN K., NEWMAN M. \& K. CHAYAMARIT (Eds.), Flora of Thailand. Volume 10, Part 3, Anacardiaceae \& Convolvulaceae. The Forest Herbarium, Bangkok. pp. 330-468.

STAPLES G.W. \& P. TRAIPERM 2008. New species, new combinations, and new records in Convolvulaceae for the Flora of Thailand. Thai Forest Bulletin Botany 36: 86-108.

VAN OOSTSTROOM S.J. 1940. The Convolvulaceae of Malaysia, III. The genus Ipomoea. Blumea 3: 481-582.

VAN OOSTSTROOM S.J. \& R.D. HOOGLAND 1953. Convolvulaceae. In: VAN STEENIS C.G.G.J. (Ed.), Flora Malesiana. Series I, Volume 4. Noordhoff-Kolff N.V., Batavia. pp. 388-512. 